\title{
Package Lot Number
}

National Cancer Institute

\section{Source}

National Cancer Institute. Package Lot Number. NCI Thesaurus. Code C93891.

An alphanumeric string used to identify a particular batch of package. 